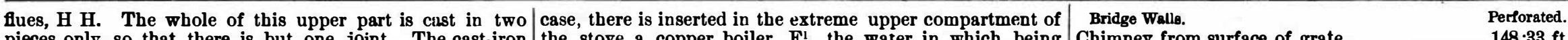
pieces only, so that there is but one joint. The cast.iron the stove a copper boiler, $\mathrm{F}^{1}$, the water in which, being Chimney from surface of grate............. 148.33 ft. then the smoke and gases proceeding from combustion cir- pipe, $\mathrm{G}^{\mathbf{1}}$, and after circulating through the rooms to be culate between the two ovals, to which they impart an ele- warmed, returns to the boiler through the pipe, $\mathrm{H}$. The vated temperature, and, after becoming cooled in part, apparatus just described are not only applicable to the

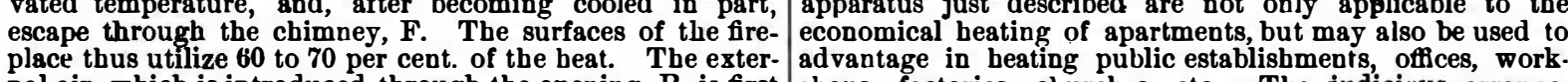
nal air, which is introduced through the opening, $R$, is first with the external surface of the oval, and a part enters the hot-air box, $M$, through the passages, $H$, and from thence escapes into the apartment through the flues, G. Fig. represents the arrangement adopted for burning coal and
coke. The back part of the chimney is lined with a refracadvantage in heating public establishments, offices, work-
sbops, factories, churches, etc. The judicious arrange shops, factories, clurches, etc. The judicious arrange-
ments adopted for the utilization of the heat allow of most results being obtained, even when it of perature of establishing and maintaining a uniform tem churches or extensive manufacturing establishments. tory clay to protect the casting.

Heating by Hot Water.- The hot-air box, which in ordinary chimneys serves to heat the air coming from out-of-doors, may be converted into a reservoir of water provided with 4 shows how such an application nay be made, without the 4 shows how such an application nay be made, without th
necessity of describing it. 'The ingress of air and the egres

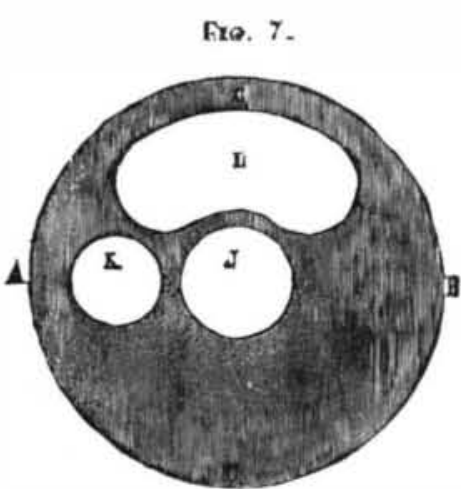

\section{STEAM BOILER FURNACES FOR SMOKE}

y JoHN W. HiLl, M.

THE Board of Commissioners of the Cincinnati Industrial Exposition (1879) offered a cash premium of five hurtred signed to burn bituminous coal without smoke. All competing devices to be submitted to expert trials, and to be durable, practical, and capable of ready application to the prevailing types of steam boilers.
Five entries were made for the trials, as follows: The Walker Twin Furnace, by R. L. Walker \& Co., of Boston Mass; this furnace formed part of the setting of an ordinary return tubular boiler at the dry goods house of John Shillito
$\&$ Co. The Fisher furnaces, by Lawrence Foulds \& Fisher, of Cincinnati; this furnace formed part of the setting of a return tubular boiler at the printing establishment of Strobridge \& Co.

The Eureka furnace attachment, by Douglass, Ludlow \& ting of a battery of $t$ wo return tubular boilers at the Lane \& Bodley Co. macline sh ops. The Price furnace, by Wm. Price, of Cincinnati; this furnace formed part of the setting of a return tubular boiler at
the Price bill inclined plane. The Murphy furnace, by Thomas Murphy, of Detroit, Mich.: this furnace was built specially for the trials, and
was set with an independent boler on the direct and drop FRENCH HEATERS AND STOVES FOR AIR AND

of smoke are regulated by registers, wbich may be closed entirely in case of fire, or to stop the passage of the air into
the chimney during the night and to keep the heat in the the ch.

Hot-Air Stoce.-Figs. 5, 6, 7, and 8 show the details of a hot-air stove constructed on the Bolo de Sevray system. On the foundation of masonry, $X$, rests the well, A, containing above it is the body of the fire-place, E, lined with fire-brick, 7), support cylinders, I, through which alternately circulate the smoke and the air to be heated. The smoke passes first
into the flues, $J$, and from thence into the flues, $K$, then traverses the compartments which are provided with smokeboxes, $M$, and reaches (as indicated by the arrows in Fig. 5) the chimney, $R$, thus coming in contact with a large amoun
of beated surface. $A$ reservoir, $T^{1}$, contains water to prevent the air from becoming too dry The air to be heated is drawn in from the outside at $\dot{V}$, and, coming in contact with the dome, a portion of it ascends around the
apparatus, while another enters through the opening, $L$, of

The connected boilers of all the furnaces, excepting the
flue plan. Murphy, furnished steam for the daily requirements of the several establishments where they were located. The steam
from the Murphy boiler was blown into the atmosphere, and wasted. THE WALKER TWIN FURNACE.

This furnace consists essentially of two independent grates, located in separate fire chambers, at opposite ends of the so arranged that when one is closed the other is opened and vice versa-control the direction given the gases of combus ion in transit to the chimney.

The grates are alternately charged with coal, the gases of quick evolution from the freshly charged coal passing through two perforated bridge wall

gluwing coal on the opposite grate.
The fire chamber containing the green coal, acts as a re tort for the distillation of the volatile matter, which matter as it passes through the air chamber and over the acid, or oxide, vapor of water and sulphurous acid.

Fig. 8.

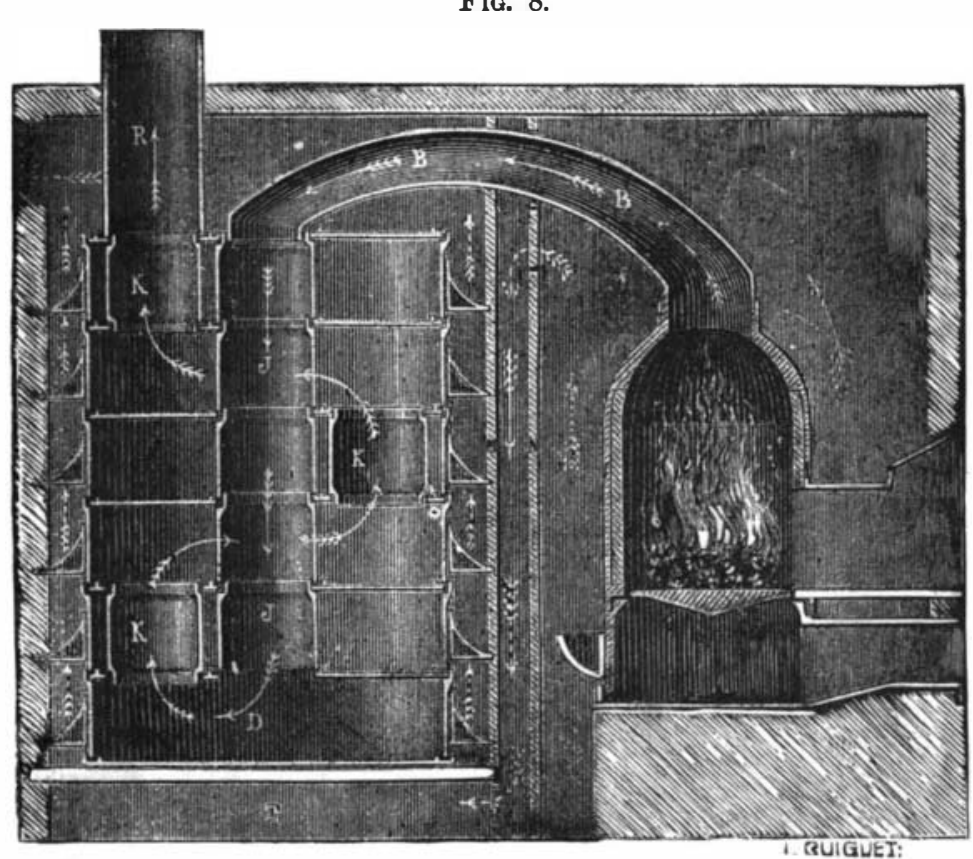

FRENCH HEATERS AND STOVES FOR ATR AND WATER.

the lower platform, diffuses itself through the compartments not occupied by the smoke, traverses the parts, L,
enters the air chamber, $\mathrm{A}^{1}$, and makes its exit through the outlet flue. The direction taken by the hot air is indicated by the arrows. The flre-brick lining of the fire-place is designed, in the first place, to prevent any wear on the cast ing; secondly, to prevent the latter from becoming red-hot, The apparatus is very durable; the only portions which are liable to wear out are the grate and fire-place, and these may be easily replaced without taking tbe stove apart. Any kind of fuel can be used in it-wood, coal, coke, etc. Fig.
8 represents a bot-air stove specially designed for cases 8 represents a hot-air stove specially designed for cast happens where it is situated in the cellar or basement. The hot-air furnace described above may be converted into the desired temperature bas been obtained and the fire well under way, both the door of the furnace and a register
at $L^{1}$ above the furnace are closed. The whole body of the fire-place is then filled witb coke, through $J$, and the regis $\mathrm{B}$. aceording to the charge of coke employed. In the secon

horizontal tubular boiler, furnishing steam for workin The building. oiler:

DIMENGIONB.

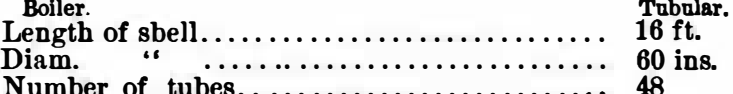

Number of tubes.......................

Heating surface shell $\ldots \ldots \ldots \ldots \ldots \ldots \ldots \ldots \ldots, 142.992$.

$804 \cdot 249$

963.637

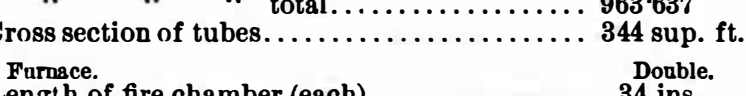

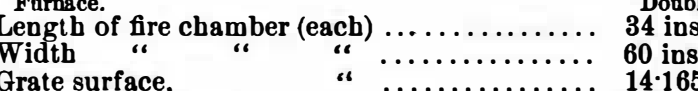

"Grate surface, " both

Heating to grate surface.

\begin{tabular}{lrr} 
Grate surface to cross-sestion of tubes.......... & 8.225 \\
\hline
\end{tabular}

Grate surface to cross-section of chimney......
Distance from grate to boiler................ 20.555

\section{THE FIBHER FURNACE}

In this furnace the ash pit is divided transversely by a brick wall built close up under the grate; two-thirds of is ash pit being forward of the division wall. The grate
in to be divided into surfaces: a forward surface nd a rear surface. The bars and air spaces of the forward surface are parallel to the axis of boiler, and inclined down -
ward seven inches in thirty-two. The rear grate is horizontal, with bars and air spaces transversely of axis of boiler The bridge is vertical, and is built up to within seven and e-half inches of the bottom of boiles.

An air duct passes from front to rear through the bridge wall; the opening in front, being directly under the rear courses of the crest of the wall.

The opening in the rear of the bridge wall is covered with perforated iron plate, through which the air is distribute fine jets. Similarly perforated onenings are provided in all. Th opposte the chamber, and ant of the bridge lides to regulate the amount of opening, or close the perrations entirely.

The furnace was set with a well proportioned return flue Ther, furnishing steam to work the elevator and machinery

The following are the principal dimensions of furnace and

Flue.

Diam. " " $\ldots \ldots \ldots \ldots \ldots \ldots \ldots \ldots \ldots \ldots \ldots \ldots \ldots \ldots \ldots \ldots, 48$ ins

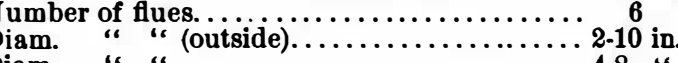

Diam. “ " “

ating surface flues. ....................

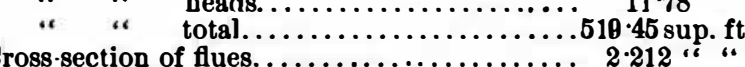

Furnace.

Wength of fire chamber.................. 50 ins.

Grate surface................................

Grate surface to cross-section of flues...............

rate surface to cross-section of chimney.....4.160

Distance from grate to boiler.............. 17.24 ins.

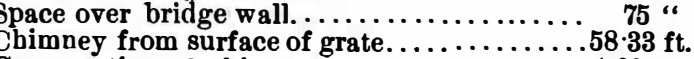

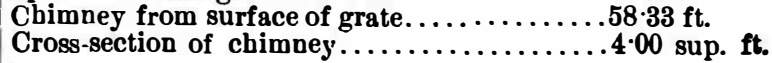

THE EUREGA FURNACE ATTACBMRNI.

This device consists of a series of steam jets, surrounded by circular bell-shaped muzzles, set iu the furnace front, Tion.

The device, as tried under a battery of two boilers, em diameter and eight air nozzles, having a free orifice, $1 \cdot 25$ diameter.

The steam nozzles are all connected to a horizontal pipe
passing across the furnace front over the fire doors. This passing across the furnace front over the fire doors. This pipe receives steam from the boilers, the flue being regulated
by an ordinary stop valve.

The furaace is unchanged in applying this attachment, front for the reception of the air nozzles. and machine shop of the Lane \& Bodley Co., and were set in the manner common to their class.

The following are the principal dimensions of furnace and

Boilers

Length of shell.

Number of tubes (each boiler)

Heating surface shells........

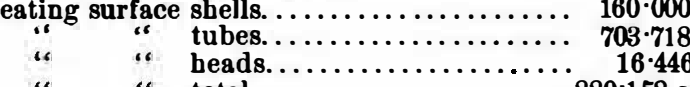

Cross section of total.

Troms secti

Length

Grate surface...

Heating to great surface.

rate surface to cross section of tubes.

Grate surface to cross section of chimney. .

Distance from grate to boil

Chimney from surface of grate.

Tubalas.

Cross section of chimney

THE PRICE YURNACE

This furnace consists of two parallel fire chambers and grate surfaces, made by dividing the usual fire chamber with ap to the boiler. Near the forward end the wall is perfor-
un up to the boiler. Near the forward end the wall is perforfire chambers. The gases of quick evolution from the green coal of one grate passes throug the throat and over the furnace. The division wall extends back to the bridge wall, which, arch embraces the bottom of the boiler.

Through the lower portion of the $b$ idge wall are cut two flues or openings, capable of being alternately closed and damper and charging of tbe coal, the two fire chambers are alternately made to act as retorts. The volatile matter from the freshly charged coal passes forward in the fire chamber, wbere it is distilled through the throat and back over th

coke on the oppositegrate.
The gases of combustion from both fire cbambers pass
back through the open flue in the bridge wall, thence through the furnace and tubes of the boiler in the usus manner. 
The following are the principal dimensions of furnace and boiler :

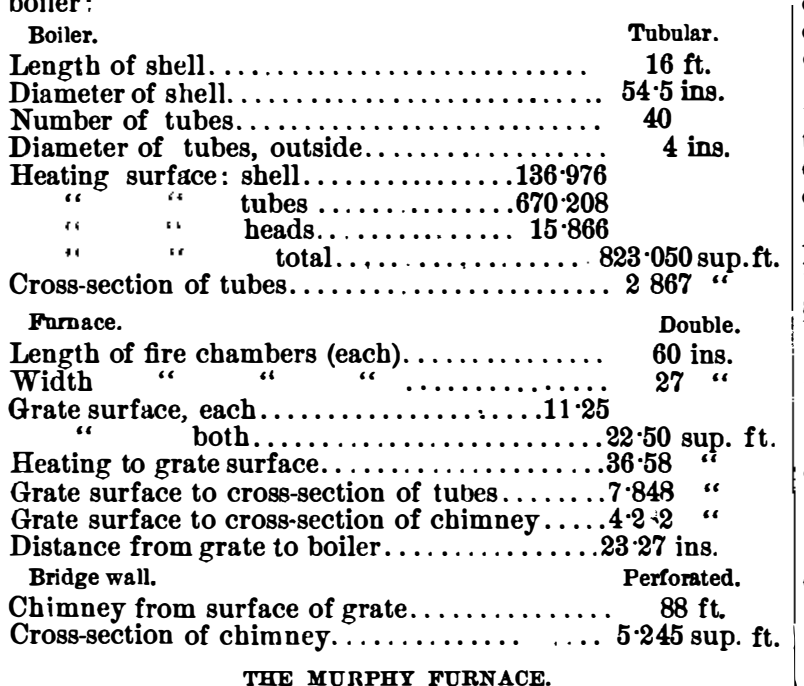

This furnace consists principally of an independent oven, set forward of the boiler (after the manner of furnaces for
burning spent tan from the leach), in which combustion is burning spent tan from the leach), in which combustion is
completed before the gases are permitted to impinge upon the heating surfaces of the boiler. In the other furnaces the bottom of the boiler forms the roof of the fire chamber. In this furnace the roof of the
fire chamber is a fire brick arch of large radius.
The grate bars are single and set to form a V-shaped fire The grate bars are single and set to forna a V-shaped fire
bed, similar to the well known Waddington grate. The grate is divided into two distinct surfaces on the axial line
of fire chamber, each section of bars being mounted at the inner end on a revolving shaker shaft, operated from the front, for the removal of clinkers and ash.

The two sections of the grate are separated at the inner ends, about six inches, for the reception of a toothed clinker
bar, the squared end of which is projected through the furbar, the squared end of which is projected through the fur-
nace front, and worked with a socket wrench. for the reception of finely broken coal, which is fed on the grate by a reciprocating plunger sliding under the mouth of
the hopper, and worked by a rock shafl from the front of
the furnace. the furnace.
All coal charged to the grate is first passed through the two hoppers, from which it is delivered in a partially coked The sharp inclination of the grate bars precipitates nearly if not quite all the fusible and vitrifying matter in the coal
upon the clinker bar, from which it is readily removed as

desired by a partial rotation of the bar.
No band stroking of the fire is necessary with this furnace; the entire manipulation of the coal, after it is charged into the magazines, being acco

The rear end of the oven terminates in a throat, through which the gases of combustion pass into the tubes of the plan, the whole tendency of the hot gas being from above downward.
A system of water heating tubes was connected to the under side of the boiler, into which the feed water was introcirculated just before passing into the chimney.
The following are the principal dimensions of furnace and boiler:

Boiler.
Length of shell

Diameter of shell.

Number of fire tubes.

Diameter " " "(outside)

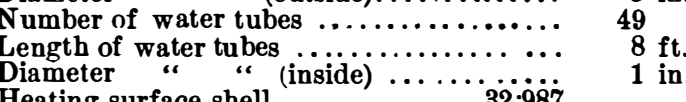

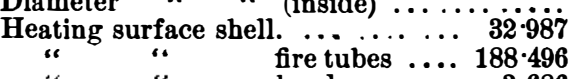
$\begin{array}{rrr}\text { fire tubes } \ldots . . & 188 \cdot 496 \\ \text { beads. ...... } & 3 \cdot 686\end{array}$ water tubes... $102 \cdot 626$

Cross-section of fire tubes $\ldots \ldots \ldots \ldots \ldots \ldots .327 \cdot 795$ sup. $f$. Length of furnace

Wrate surface.

Heating to grate surface

Grate surface to cross-section of fire tubes..

Chimney from surface of grate. ....

36 in.

10.50 sup. ft.

Pittsburg coal was chosen for the trials for several rea sons: First, the high percentage of volatile matter and diffcult coal to work in furnacee designed for smoke prevention, and a furnace capable of working this coal success
fully (in the matter of smoke prevention) can be relied upon to furnish equivalent, if not better, results with any other coal. Second, Pittshurg coal contains a higher percentage
of combustible and a higher thermal value per unit of com. brained from thy other known coal; as economic result furnace under the conditions of trial. Third, Pittshur coal is well known wherever bituminous coal is used in the
United States, and the results of trials with this coal can be easily compared with the results of many former trials reduced to a Pittsburg.coal basis.
The coal used for the trials was obtained from the yards
of Marmet $\&$ Co (Cincinnati), and was of excellent quality From the analysis for the purpose of the trials by Prof Bruno Kniffer, and the known distribution of heat in the
trial of the Murphy furnace, the thermal value of the com trial of the Murphy furnace, the thermal value of the com-
bustible bas been taken at 15,500 units. The coal was weighed to all the fur

urphy in uniform charges of 200 pounds. The comparatively small dimensions of the Murphy fursuggested the propriety of uniform charges of 100 pound in this instance.

The charges (time and weight) of coal were noted and
checked independently by two observers. and no charge was permitted to be removed from the scale until both observers in their note books
At the end of trial, after the ìre was restored to its original
condition under the direction of the writer, the unburnt coal was weighed back and deducted from the total quantity harge The fire and ash pit having been carefully cleaned at commencement of trial, all ash and clinker on the grate and in
the ash pit at end of trial was weighed back dry, and the difference between this weight and the net weight of coal charged, is held to represent the weight of combustible fired.
of the weight of ash and clinker returned was a small rcentage of combustible, which worked through the grate, the value of which is obtained by deducting from the ob-
served weight of non-combustible, the weight of non-comserved weight of non-combustible,
bustible as determined by analysis

Eacb competitor had complete control of his coal and fur ace during the trial.

The water delivered to the boilers was measured in a tight ank, divided into two compartments, one compartment containing $1,728^{\circ} 5$ pounds, and the other $1,727.0$ pounds,
with water at $70^{\circ} \mathrm{Fahr}$. In the upper edge of the partition dividing the tank a notch was cut with beveled edges. crest of the dividing partition, from the city mains, and drawn down to the lower edge of the outlet pipe in the side the measuring tank for all the trials.

From either compartment of the measuring tank the water was drawn into a supplemental tank connected with
he feed pump. The level of water in the supplemental the feed pump. The level of water in the supplemental anks charged together with the final partial tank, held to epresent the total delivery of water to the boilers during To determine the thermal value of steam furnished by the boiler, a small quantity was drawn through a calorimeter in condensed. The condensation was collected in a tigh
ind periodically weighed. The water expended in condensing the steam was measured into a tight barre
rough a worthington meter. From the barrel the water entered the condenser at the
otton at a normal temperature and passed out at the top an elevated temperature; the elevation of temperature Fisher. which was all it contained, except the small quantity
resident in the condensation as it flowed from the end of

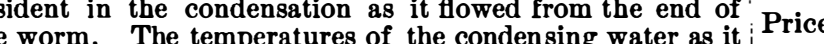

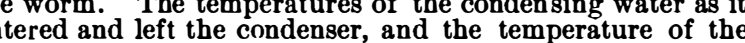
ondensation as it left the worm, were read to quarter de- Murphy The regularly every fifteen minutes.

The observations of smoke issuing from the chimney were Fen regularly every seven and one-half minutes during the Walker rial, except in cases when the darkness near the end of trial Fisher. In reading the chimney, the following arbitrary code gov- Price...
Murphy The entire absence of smoke was taken at 100, indicating
he best possible smoke-prevention. Faint traces of smoke ine best possible smoke-prevention. Faint traces of smoke n the waste gases was taken at 90, indicating a result some-
imes obt ained with an excellent construction of furnace and mes obtained with an excellent construction of furnace and
skillful manipulation of the fire. Discoloration of the aste gases, readily perceptible, was taken at 75, indicating a state of sinoke-prevention above the average of furnace
was taken at 50. Fairly black issuing from the chimney

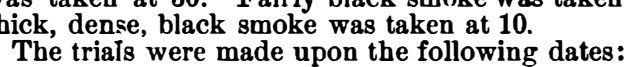

Walker furnace.

Eureka

attachmen

Oct.

Walker.

Eureka.

Price....

To determine the amount of heat expended in elevating The demperature of the vapor of water in the air hygrometer,
readings were made balf hourly during each trial, with the ollowing results, as means of twenty-one observations:

The trials were limited to ten hours each by reason of all the furnaces, excepting the Murphy, being in manufacturing
establishments, where night runs would have been objected to

The duration of trials was as follow

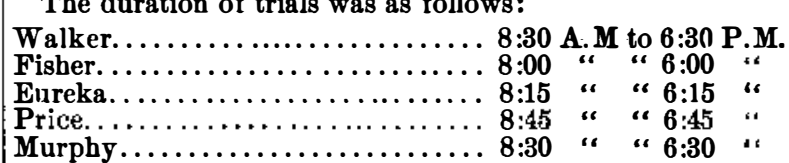
The steam pressures were read from a Bourdon gauge
which had been carefully prepared for the trials, and the following are means of forty-one readings:

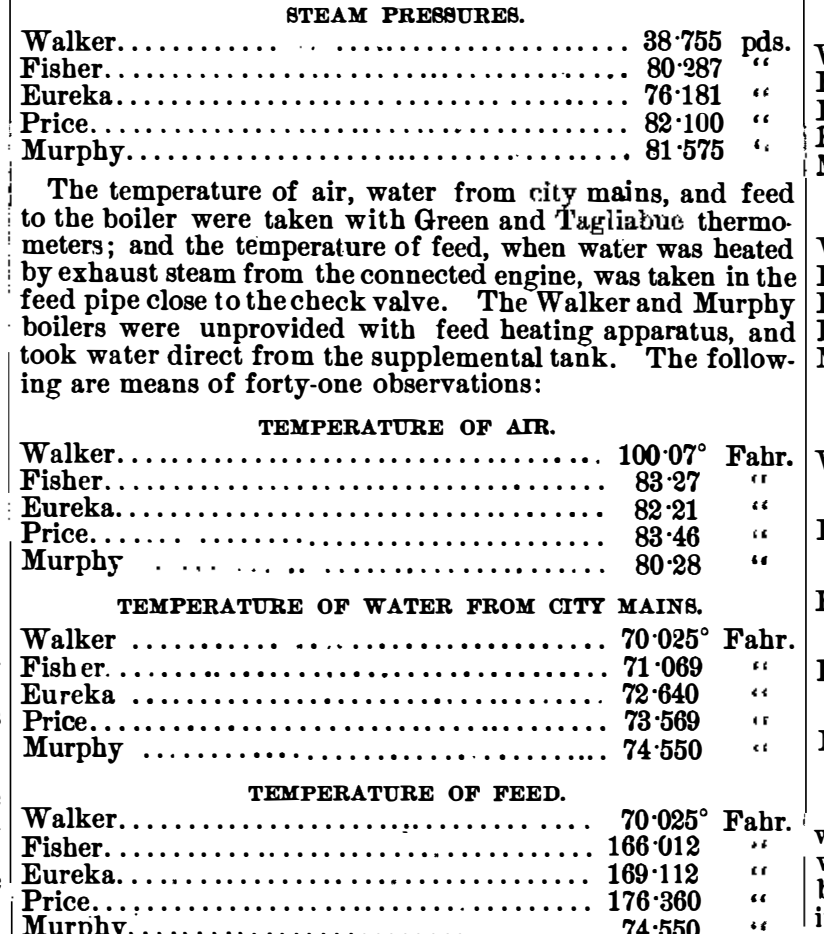

furnished is calculated, have ween averaged for each trial, and are given in the following table:

INITIAL TEMPERATURE, CONDENSING WATER.

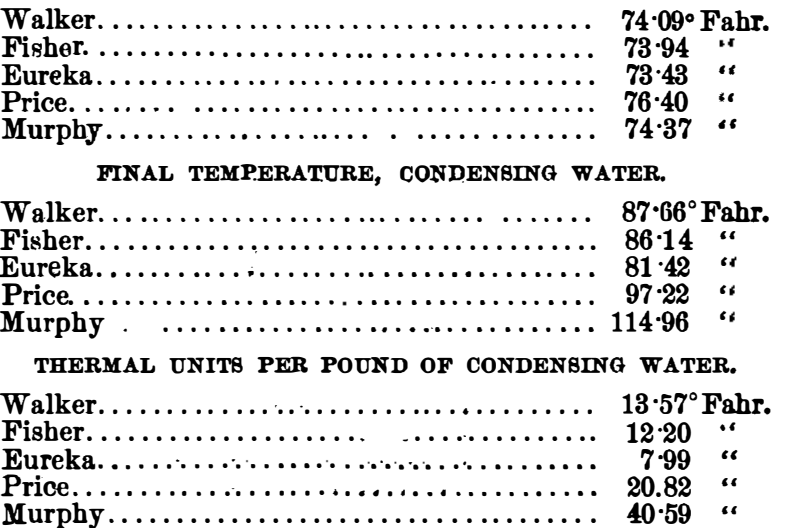

TEMPERATURE OF CONDENAATION

$85 \cdot 43^{\circ}$ Fahr.

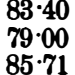

$79 \cdot 00$
$75 \cdot 71$
$77 \cdot 08$

CONDENGING WATER, PER POUND OF BTEAM. 3288.75 wate

\begin{tabular}{|c|c|c|c|c|}
\hline ker. & $\begin{array}{r}51 \\
1004 ! 5\end{array}$ & $\begin{array}{l}\text { steam } \\
\text { water }\end{array}$ & $64 \cdot 483$ & pound \\
\hline Fisher..... & $\begin{array}{c}139 \\
6633 \cdot 61\end{array}$ & $\begin{array}{l}\text { steam } \\
\text { water }\end{array}$ & $72 \cdot 24 n$ & “" \\
\hline Eureka. & $\begin{array}{r}67 \cdot 18 \\
6362.82\end{array}$ & $\begin{array}{l}\text { steam } \\
\text { water }\end{array}$ & $116 \cdot 012$ & “ \\
\hline Price. & $\begin{array}{r}93 \cdot 25 \\
5564 \cdot 70\end{array}$ & $\begin{array}{l}\text { stearn } \\
\text { water }\end{array}$ & $68 \cdot 233$ & “ \\
\hline
\end{tabular}

The utter unreliability of boiler efficiency, based upon the water pumped into the boiler, and the coal fed on the grate, was never better shown than by these trials. None of the boilers were hard worked, and without data to the contrary, it would naturally be supposed that the low rate of evapora$\begin{array}{l:l}\text { The pressure of atmosphere was read from a compensated } & \text { tion per unit of beating surface and low rate of coal con- } \\ \text { sumption per unit of grate surface would guarantee saturated }\end{array}$ observations:

Walker.

Eurice. .

$29 \cdot 760$ ins
$29 \cdot 693$ ":
29.630
$29 \cdot 334$

In the following table the heat per pound of steam is based upon the total water fed to boiler, or rather upon the proportion of that water as evaporation diverted to the condenser. In the Walker, Fisher, and Eureka boilers, a material portion of the water pumped in was entrained in the
steam, producing a mean thermal value per pound of steam 
considerably less than that of saturated steam at observed
pressures. Cpon the other hand the Price and Murphy steam

urphy steam ' was 964.73 units, and total beat per pound of coal in the TOTAL HEAT PER POUND OF GTEAM CONDENBED. Walker.

Fisher.

$960 \cdot 46$ units
$964 \cdot 73$ "
$1005 \cdot 93$
$156 \cdot .32 "$,
$1441 \cdot 35$

Murphy $1566 \cdot 32$

The air entering the furnace per pound of combustible thermal value of the combustible, and nean specific heat of the gases of combustion.

The mean observed temperature of fire in the Walker fur-?
nace was $1931 \cdot 24$, and taking the mean specific beat of the gases of combustion at 0.238; then the weight of bot gas per pound of combustible becomes

$$
\frac{15,500}{(1931 \cdot 24-100 \cdot 07)}+\frac{0.238}{2}=35.565 \text { pounds. }
$$

Of this quantity one pound was combustible from the coal. The mean observed temperature of fire in the Fisher fur-
nace was 1902.94; and the weigbt of hot gas per pound of nace was 19v2.94; and the weight of hot gas per pound of
combustible $\frac{15,500}{100}=35.789$ pounds. Of this combustible $\overline{(1902 \cdot 94-83 \cdot 27) 0 \cdot 238}=35 \cdot 789$ pounds. Of this
quantity one pound was combustible from the coal. The mean observed temperature of fire in the Eureka fur-
nace was 2369 '30; and weight of hot gas per pound of combustible $-\frac{15,500}{(2309 \cdot 30-82 \cdot 21) 0.238}=28 \cdot 475$ pounds. Of this quan tity one pound was combustible from the coal.
The mean observed temperature of fire in the Price furnace was $3053 \cdot 00 ;$ and weight of hot gas per pound of com bustible 15,500 (30 $73-83 \cdot 46)$ $=21.931$ pounds. Of this quantity $(30 \cdot 3-83 \cdot 46) 0 \cdot 238$
pound was combustible from the coal. The mean observed temperature of fire in the Murphy furnace was 3056 75; and weight of hot gas per pound of combustible $\frac{15,300}{(3056 \cdot 75-80 \cdot 28) 0 \cdot 238}=21 \cdot 880$ pounds. Of this quantity one pound was combustible from the coal. AIR PER POUND OF COMBUtitile.

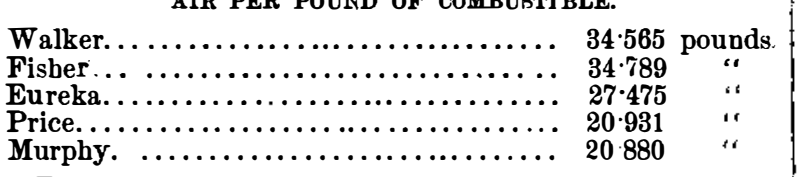

The weight of vapor of water in the air supporting combustion is stated in decimal of a pound per pound of air supplied.
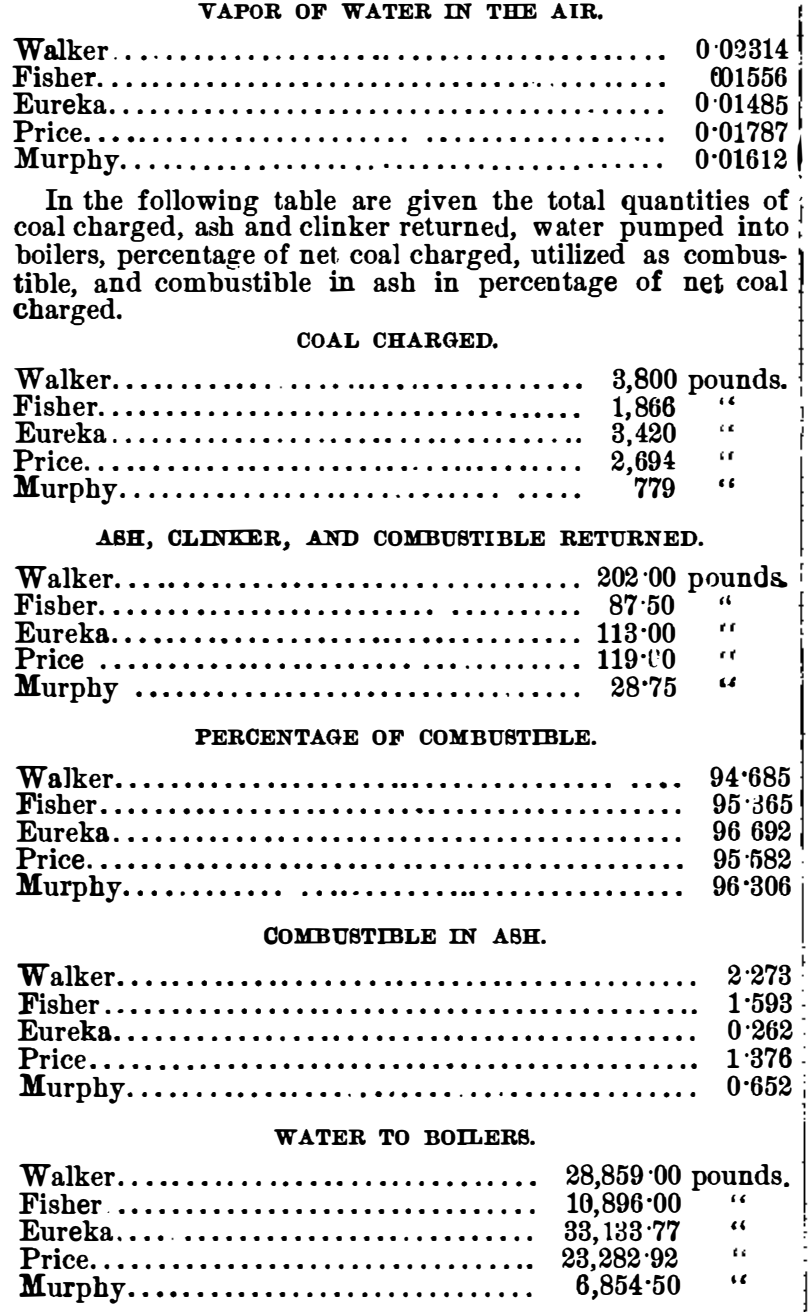

\section{EVAPORATION}

The apparent evaporation per pound of coal with the Walker furnace and boiler was $\frac{28859}{3800}=7.5946$ pounds; but the mean heat per pound of steam condensed in the calori-
meter was 960.46 units, and total heat per pound of coal in the steam was $7 \cdot 5945 \times 960 \cdot 46=7294 \cdot 21$ units. Of this quan tity $70.025 \times 7.5945=513.8$ units were in the feed water, and the evaporation per pound of coal from and at a temperaThe combustible was 0.94685 of net coal charged and evapo-
ration per pound of combustible, from and at $212^{\circ} \mathrm{Fahr}$. was $\frac{7 \cdot 019}{0.94685}=7 \cdot 413$ pounds.

The apparent evaporation per pound of coal with the

Fisher furnace and boiler was $\frac{10896}{1866}=5.839$ pounds; but the evaporation per poued of coal from
was $\frac{1262.58-(555.973}{966}=12.4499$ pounds. steam was $5 \cdot 839 \times 964 \cdot 73=563: 3.058$ units. Of this quantity $166.012 \times 5 \cdot 839=969 \cdot 34$ units were in the feed water, and the evaporation per pound of coal from and at a tempers

of $212^{\circ}$ Fabr. was -966
The combustible was 0.95365 of net coal charged and evapoThe combustible was 0.95365 of net coal charged and evapo-
ration per pound of combustible from and at $212^{\circ}$ Fabr. was $\frac{4 \cdot 8 \cdot 28}{0.95365}=5.062$ pounds.

The apparent evaporation per pound of coal with the Eureka furnace and boiler was $\frac{33133 \cdot 77}{3420}=9 \cdot 688$ pounds; but the mean beat per pound of steam condensed in the calorimeter
was 1005.y3 units, and total beat per pound of coal in the steam was $1005.93 \times 9 \cdot 6 \mathrm{t}=9,745 \cdot 45$ units. Of this quan-
tity, $169 \cdot 112 \times 9 \cdot 688=1638 \cdot 357$ units were in the feed water and evaporation per pound of coal from and at $212^{\circ} \mathrm{Fater}$. was $-9745 \cdot 45-1638 \cdot 357=8.392$ pounds.

The evaporation by the Eureka boiler should be reduced.

by the amount of steam expended in maintaining the jets.
The orifices in the nozzles were 0.0625 in. diameter, and area f eight nozzles $8 \times 00625^{2} \times 0.7854=0.00017$ sup. ft.

Considering the form of the nozzle and approach thereto, of orifice was abrut 1,000 feet per second from which is ob tained the weight of steam expended per hour in the jets, as

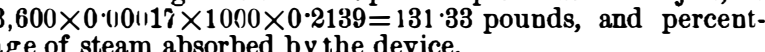
$\frac{131 \cdot 33}{254 \overline{5}}=0 \cdot 0516 . *$

From which is deduced the net evaporation per pound of Murphy
. The combustible was 0.96692 of net coal charged, and
aporation per pound of combustible from and at $212^{\circ} \mathrm{Fahr}$. was $\frac{7.959}{0.96692}=8 \cdot 231$ pounds.

The apparent evaporation per pound of coal with the

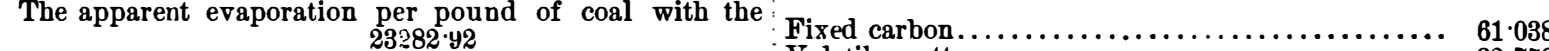

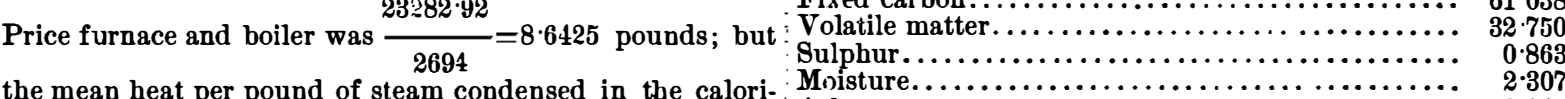

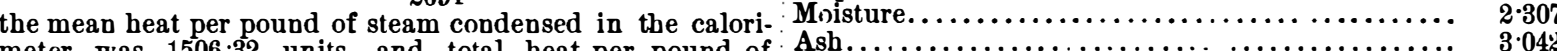
meter was $1506 \cdot 32$ units, and total heat per pound of
coal in the steam was $15,6 \cdot 62 \times 8.6425=13018.37$ units. Of this quantity $176 \cdot 36 \times 8 \cdot 6425=1524 \cdot 17$ units were in the water, and the evaporation per pound of coal from and at $212^{\circ}$ Fahr. was $\frac{13018 \cdot 37-1524 \cdot 17}{966}=11 \cdot 8988$ pounds.

966
The combustible was 0.95582 of net coal charged, and evaporation per pound of combustible from and at $212^{\circ}$ Fahr. was $\frac{11.588}{0.9582}=12 \cdot 449$ pounds.

The apparent evaporation per pound of coal with the Wurphy furnace and boiler was $\frac{6854 \cdot 5}{779}=8 \cdot 7991$ pounds; but the mean heat per pound of steam condensed in the calori-
meter was 1441.35 units, and total heat per pound of coal meter was $1441 \cdot 35$ units, and total heat per pound of coal $74 \cdot 5.5 \times 8 \cdot 7991=665.973$ units were in the feed water and the evaporation per pound of coal from and at $212^{\circ}$ Fahr.

The combustible was 0.96306 of net coal charged, and $\frac{12 \cdot 4499}{0 \cdot 96306}=12 \cdot 9274$ pounds.

CAPACITY OF BOILER.

The rate of evaporation per superficial foot of heating surboiler, $\frac{7 \cdot 019 \times 380}{963 \cdot 637}=2 \cdot 7679$ pounds.

For the Fisher boiler, $\frac{4.828 \times 186 \cdot 6}{\frac{519 \cdot 45}{7 \cdot 959 \times 342}}=1.7343$ pounds.

For the Eureka boiler, $\frac{7 \cdot 959 \times 342}{880 \cdot 158}=3 \cdot 2062$ pounds.

For the Price boiler, $\frac{11 \cdot 8988 \times 269 \cdot 4}{823.05}=3.8917$ pounds.

For the Murphy boiler, $\frac{12 \cdot 4499 \times 77 \cdot 9}{327.795}=2 \cdot 9587$ pounds.

RATE OF COMBUSTION.

The coal charged per superficial foot of grate per hour,

was for the Walker furnace, $\frac{380}{28 \cdot 33}=13 \cdot 413$ pounds.

For the Fisher furnace, $\frac{186 \cdot 6}{16 \cdot 64}=11 \cdot 214$ pounds.

For the Eureka furnace, $\frac{342}{24}=14 \cdot 25$ pounds.

For the Price furnace, $\frac{269 \cdot 4}{22 \cdot 50}=11 \cdot 973$ pounds.

For the Murphy furnace, $\frac{77 \cdot 9}{10 \cdot 5}=7 \cdot 419$ pounds.

* In the report of this trial to the Commiseioners of the Exposition, a
error occurs in tuating the fraction of total steam $\mathrm{e}$ pended in maintain

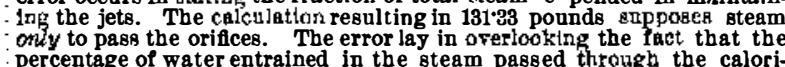
percentage of water entrained in the steam passed through the calori
meter would also \&ppiy to the steam passed by the jets. In other words
the denominator of the fraction representing the steam expender in main

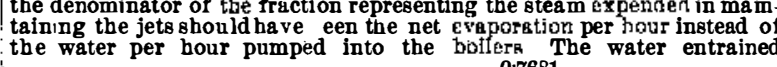
( $23 \cdot 19$ per cent.) had a relative volume of ${ }^{291 \cdot 60} 0.7681=065$ or 1 per cent. of
RESUME OF RESULTS.

Steam per pound of coal from and at $212^{\circ} \mathrm{Fahr}$.

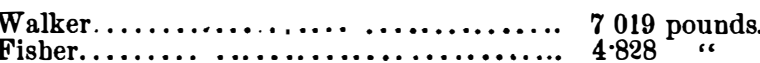
rice.....

$7 \cdot 959$

Steam per pound of combustible from and at $212^{\circ} \mathrm{Fahr}$.

Walker............................. $\quad \mathbf{7} \cdot 413$ pounds. Eureka.

$8 \cdot 231$
$12 \cdot 449$

Steam per sup. foot of healing surface per hour

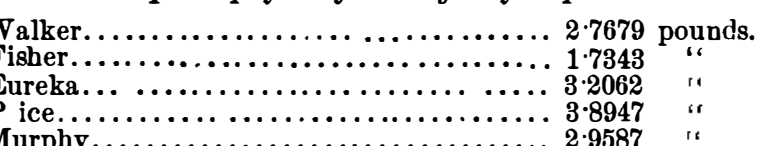

Coal per sup. foot of grate surface per hour.

isher........................................ $13 \cdot 413$ pounds.

Price.

SMOKE PREVENTION.
In comparing results in the following table it should be

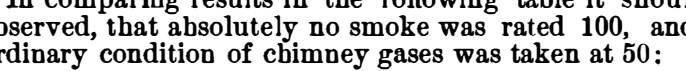

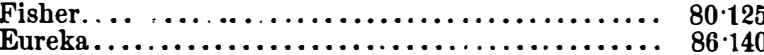

$\begin{array}{ccc}81 \cdot 202 \\ \ldots \ldots \ldots & 98 \cdot 467\end{array}$

THE DISTRIBUTION OF HEAT.

Specimen lumps of coal were taken from the several lots rnished the competitors in the trials, and submitted to nalysis by Prof. Bruno Kniffler, with the following re$\overline{100 \cdot 000}$

As already stated, the thermal value of the combustible has been taken at 15,500 units; equivalent to an evaporation
from and at $212^{\circ} \mathrm{Fahr}$. of 16.045 pounds.

Steam

Chimney

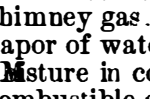

WALKER FURNACE.

$3734 \cdot 725$
$169 \cdot 415$

$169 \cdot 415$
$30 \cdot 070$

$30 \cdot 070$
$775 \cdot 000$

$3629 \cdot 635$

15500000

$\begin{array}{rr}\text { Steam. } & \text { Percentage. } \\ 7 \cdot 413 & 46 \cdot 201 \\ 3 \cdot 866 & 24 \cdot 095\end{array}$

\begin{tabular}{rr}
0.802 & $5 \cdot 000$ \\
3.758 & $23 \cdot 417$ \\
\hline
\end{tabular}

$\frac{23 \cdot 417}{100 \cdot 000}$

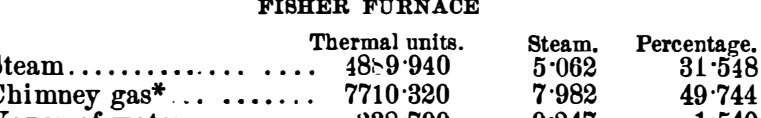

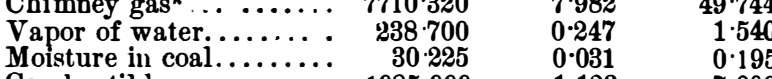

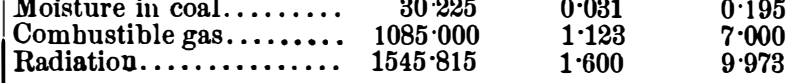

$\overline{15500 \cdot 000} \quad \overline{16.045} \quad \overline{100 \cdot 060}$

EUREKA FURNACE.

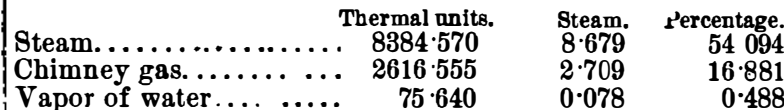

$\begin{array}{llll}\text { Vapor of water............ } & 75.640 & 0.078 & 0.488 \\ \text { Moisture in coal.......... } & 28.985 & \mathbf{0} 0.030 & \mathbf{0} \cdot 187\end{array}$

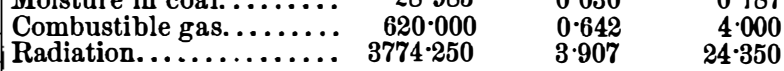

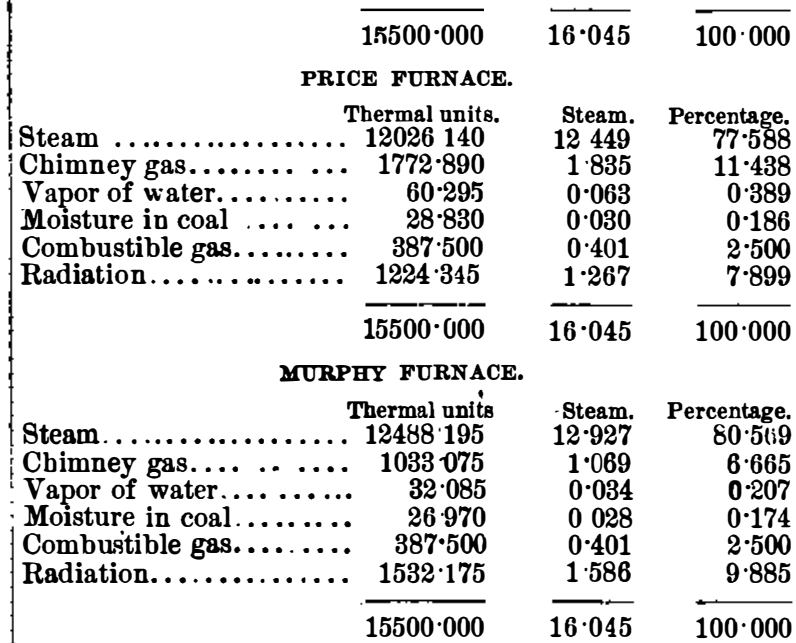

In the tables above the first four quantities are calculated from known data. No analysis having been made in eithe of the trials of the chimney gases, the percentage or therma
value per pound of combustible of the combustible gas lost in the chimney is not known.
A careful comparison of the data with that of previous trials when the chimney gases have been analyzed, suggests
the values given to the combustible gas in the tables; and the heat lost by conduction and radiation is taken as the of combustion.-Van Nostrand's Magazine. * The air opening in the bridge wall and in the side walls of the
Fisher furmace behind the bridge wall are equal to the effective area of

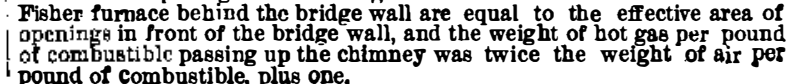

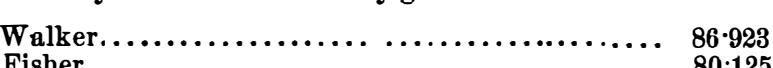

